\title{
Individual Versus Group Argumentation: Student's Performance in a Malaysian Context
}

\author{
Lee Ling Heng ${ }^{1}$, Johari Surif ${ }^{1} \&$ Cher Hau Seng ${ }^{2}$ \\ ${ }^{1}$ Department of Science and Mathematics Education, Faculty of Education, Universiti Teknologi Malaysia, \\ Malaysia \\ ${ }^{2}$ School of Electrical, Computer and Telecommunications Engineering, University of Wollongong, Australia \\ Correspondence: Lee Ling Heng, Department of Science and Mathematics Education, Faculty of Education, \\ Universiti Teknologi Malaysia, UTM Skudai, 81310 Johor, Malaysia. Tel: 60-107-605-682. E-mail: \\ chua.heng@hotmail.com
}

Received: May 5, 2014 Accepted: June 9, 2014 Online Published: June 26, 2014

doi:10.5539/ies.v7n7p109 URL: http://dx.doi.org/10.5539/ies.v7n7p109

\begin{abstract}
Scientific argumentation has been greatly emphasized in the National Science Standard due to its ability to enhance students' understanding of scientific concepts. This study investigated the mastery level of scientific argumentation, based on Toulmin's Argumentation Model (TAP), when students engage in individual and group argumentations. A total of 120 students were selected and were first randomly divided into two groups to answer the Scientific Argumentation Test (ScAT). One group of students answered individually, while the other group was allowed to collaborate among group members. The Student Semi Structured Interview (SSSI) and Teacher Semi Structured Interview (TSSI) were also conducted on a selected group of students and their teachers to gather additional information to support the ScAT data. The findings showed that there is a significant difference in the mastery level of scientific argumentation between groups and individuals. Students who participated in group argumentation tend to perform better than those who participated in individual argumentation. However, the mastery level of scientific argumentation for both groups of students was generally unsatisfactory. Therefore, the teaching and learning of science in Malaysian schools need to emphasize more on group argumentative activities to enhance students' mastery of scientific argumentation, which will also their reasoning capabilities and scientific knowledge.
\end{abstract}

Keywords: acids and bases, individual argumentation, group argumentation, scientific argumentation

\section{Introduction}

Scientific argumentation is one of the criteria used to assess students, and it has been greatly emphasized in the National Science Standard (American Association for the Advancement of Science, 1993; National Science Education Standards, 1996). According to the National Research Council (NRC), one of the main goals of science education is to enhance students' scientific literacy. This is so that students could develop their skills in scientific argumentation through an inquiry process; students would first study and present some data to their classmates, and the information presented is then criticized, debated and revised (Duschl \& Osborne, 2002; Sandoval \& Reiser, 2004; Zembal-Saul, 2009). Findings from current literature indicated that scientific argumentative activities can promote students' scientific literacy (Braaten \& Windschitl, 2011; Cavagnetto, 2010; Driver, Newton, \& Osborne, 2000; Duschl \& Osborne, 2002; Sampson \& Clark, 2011), nurture conceptual changes (Nussbaum \& Sinatra, 2003; Nussbaum, 2011), and enhance their understanding of scientific concepts (Driver et al., 2000; Nussbaum, 2011; Sadler, 2004). Besides, scientific argumentation also fosters students' content knowledge (Zohar \& Nemet, 2002), develops higher order thinking (Eskin \& Berkiroglu, 2008), improves communication skills (Marttunen, 1994; Nussbaum, 2011), and enhances scientific reasoning (McNeil \& Pimentel, 2010).

In Malaysia, scientific argumentation has been emphasized through the adoption of reasoning skills in the Kurikulum Standard Sekolah Rendah (KSSR) (2011). However, scientific argumentation has not been highlighted in the teaching and learning of secondary level science subjects (Heng \& Johari, 2013). Hence, this study aims to examine the mastery level of scientific argumentation among secondary level chemistry students through individual and group argumentations. 


\subsection{Scientific Argumentation in the Teaching and Learning of Science in Malaysia}

Malaysia strives to become a fully developed nation by the year 2020 as envisaged by the former Prime Minister, Tun Dr. Mahathir Mohammad. In order to achieve this vision, science education plays an important role in the development of the nation. Students need to be equipped with the ability to think and argue scientifically. The involvement of students in argumentative practices will help them understand how knowledge is generated, justified and evaluated, and how such knowledge can be used to solve problems in everyday lives (Sampson \& Clark, 2009). Failures to engage students in scientific argumentation can falsely portray science as the unproblematic collection of facts from about the world (Newton, Driver, \& Osborne, 1999). This will cause students to purely memorize facts while learning about science.

Current studies in Malaysia have indicated that the mastery level of scientific argumentation is not satisfactory among tertiary level science education students (Heng, Johari, \& Yazid, 2012) and secondary level science students (Heng, Johari, \& Seng, 2013). The studies have showed that students have difficulty justifying their claims or answers using appropriate scientific explanations (Heng et al., 2012, Mohd-Ali, Salmiza, Zurida, \& Ahmad-Nurulazam, 2003). In addition, students often constructed simple arguments that only composed of a claim and evidence; students were weak in presenting scientific argumentation elements such as warrant, backing and qualifier. This may be due to their lack of experience and exposure to scientific argumentative activities in science classes (Newton et al., 1999). According to Mason (1996), there is a need for students to be engaged in scientific argumentative activities and be explicitly taught through suitable instruction, task structuring and modeling. It was also emphasized by Duschl and Osborne (2002) that the teaching of science as a process of inquiry without the opportunity to engage in argumentation is a failure to develop students' understanding. In spite of that, studies have shown that students rarely have the opportunities to engage in scientific argumentation (Heng \& Johari, 2013; Newton et al., 1999; Simon, Erduran, \& Osborne, 2006).

The present education system in Malaysia is still largely examination-based and teacher oriented (Heng \& Johari, 2013; Hong \& George, 2011). The teaching and learning of science heavily emphasize on teacher exposition with students as passive learners (Mohd-Ali \& Shaharom, 2003). For instance, science lessons generally start with the teacher examining previous work, introducing a topic, explaining the content, and giving instructions on activities to be undertaken. Students would then carry out activities such as answering questions or conducting experiments, according to the instructions provided in the textbook. Finally, the lesson would end with the discussion of answers, cleaning of apparatus, and noting down of homework. In such scenarios, it seems that most teachers mainly focused on asking close-ended questions and then providing explanations, while students mainly focused on listening and responding to questions based on reference materials (Tay \& Arshad, 2008). Such practices do not encourage students to elaborate further on their reasoning, which hampers their scientific argumentation skills. In addition, most of the experimental work is merely closed practical or "cookbooks" to verify theories learned in class. As such, students tend to follow blindly procedures, provided by teachers or textbooks, to carry out experiments and record their observations (Heng \& Johari, 2013). Hence, very little time is spent on discussing the scientific ideas behind an experiment and interpreting the findings. Moreover, argumentative activities such as group discussions, presentations, debates, and question-answer sessions are rarely conducted in secondary level science classes (Heng \& Johari, 2013). Therefore, the instructional approach used for the teaching and learning of science in Malaysian secondary schools only trains students to memorize scientific facts (Hong \& George, 2011) and do not help them with their development of scientific argumentation. As a result, this affects their ability to master scientific argumentation.

\subsection{Scientific Argumentation Model}

An influential contributor to the field of argumentation is Stephen Toulmin. His model of argument, referred to as the Toulmin's Argumentation Pattern (TAP) (Toulmin, Rieke, \& Janik, 1979) has been used to assess students' argument and to support their learning. According to the TAP, an argument includes a claim, data that support the claim, warrants that provide a link between the data and the claim, backings that strengthen the warrants, rebuttals that indicate the circumstances under which the claim would not be true, and qualifiers that state the conditions under which the claim is true. The TAP is depicted in Figure 1. 


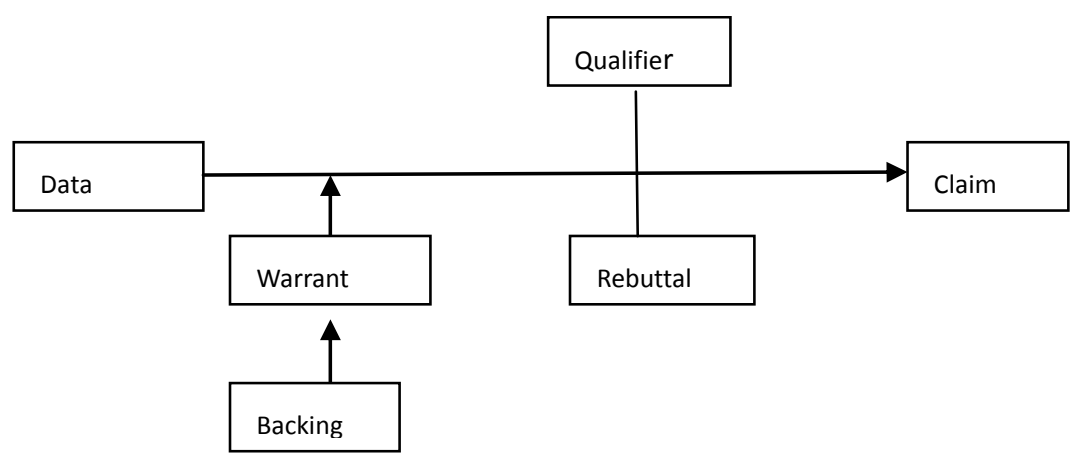

Figure 1. Toulmin's argumentation pattern (TAP)

The TAP has been used in numerous studies to analyze the elements of argumentation and the quality of each argument (Bell \& Linn, 2000; Dawson \& Venville, 2009; Erduran, Simon, \& Osborne, 2004; McNeil \& Pimentel, 2010). It is noted that the application of the TAP is based on the assumption that the presence of more argumentation elements indicates a better quality argument. Arguments that consist of claims supported by data, warrants, and backings are considered simple arguments, whereas arguments that consist of qualifiers and rebuttals, in addition to data, warrants, and backings, are deemed more complex and sophisticated. It is also noted that the TAP does not take into consideration the accuracy of the elements from a scientific perspective. In addition, the TAP also does not assess whether the argument, as a whole, makes sense (Sampson \& Clark, 2009). Thus, in this study, a rubric was constructed to be incorporated with the TAP to examine students' mastery of scientific argumentation. This allows the identification of scientific argumentation elements as well as the accuracy of scientific concepts.

\subsection{The Effects of Argumentation Activities}

The construction of scientific arguments requires cognitive involvements, such as analyzing and making sense of the data, generating explanations, supporting the idea, and challenging the validity of an idea. Previous studies by Phelps and Damon (1989) have shown that groups tend to perform better than individuals on complex tasks, such as problem solving and reasoning. In group collaborations, students have the opportunities to explain their thinking about a phenomenon being studied (King, 1990), to listen to the explanation of their peers (Coleman, 1998; Webb, 1985), to observe the strategies of others (Azmitia, 1988), and to resolve different perspectives through discussions (Amigues, 1988; Phelps \& Damon, 1989). Mason (1998) also found that group discussions involving collaborative reasoning and arguments lead to a deeper understanding of scientific concepts. Through explicating, comparing and challenging ideas, and explaining, students were able to recognize limitations, anomalies and fallacies of the concept being discussed. This situation is important and can lead to the conceptual change when students try to integrate new knowledge with existing conceptual structures.

Although the above studies suggested that the participation in group argumentation may be more beneficial than individual argumentation for individual learning, several studies suggested that the benefits of group collaboration for individual learning do not exist by just having students work in groups; rather, it depends on the involvement of students during the collaborative activities (Cohen, 1994). Only students who took initiatives to ask for help, and then applied the ideas to solve the problem showed an increase in performance. Students who simply played a passive role may achieve high performance in group work but low performance in individual work.

While the study by Mason $(1996,1998)$ showed that group collaboration supports students in gradually mastering new knowledge, studies have also shown that it is difficult to involve students in the activities of scientific argumentation, such as expressing ideas, providing criticism, discussing and revising ideas (Jimenez-Aleixandre, Rodriguez, \& Duschl, 2000; Sadler, 2004; Sampson \& Clark, 2009). Some of the learning processes, such as resolving different ideas through discussions and providing criticisms may not occur in group argumentation. In addition, many of the learning processes described above also exist in individual argumentation, especially when one thinks more deeply about, or try to integrate new information with existing knowledge (Sampson \& Clark, 2009). Therefore, while learning processes that occur in both individual and group argumentations promote the learning of scientific concepts, a proper comparison between the students' mastery level of scientific argumentation in groups and as individuals requires further investigations. 


\subsection{Research Objective}

The aim of this study is to examine and to compare the mastery level of student's scientific argumentation in individual and group argumentations. Specifically, the objectives are as follows:

(1) To compare the mastery level of scientific argumentation among secondary level chemistry students, engaged in individual and group argumentations.

(2) To compare the mastery level of scientific argumentation elements among secondary level chemistry students through individual and group argumentations.

\section{Method}

\subsection{Research Design}

The study conducted was a mixed method descriptive research to examine students' mastery level of scientific argumentation, based on the TAP. Quantitative analyses were carried out to gather information related to the mastery of scientific argumentation. The findings were also supported by comprehensive qualitative data. To achieve the objectives of this study, three instruments, Scientific Argumentation Test (ScAT), Student Semi Structured Interview (SSSI) and Teacher Semi Structured Interview (TSSI) were developed. The ScAT was carried out through two methods, namely individual and group argumentation, to determine and compare the mastery of scientific argumentation on the concepts of acids and bases. The SSSI and TSSI were then conducted on a selected group of students and their teachers to support the ScAT data.

\subsection{Participants}

A total of one hundred and twenty (120) chemistry students (62 female and 58 male), selected from four schools in the district of Pasir Gudang, Johor, first answered the ScAT as an individual or in groups of four. Then, eight (8) students from individual argumentation and twenty (20) students (five groups) from group argumentation were selected using a purposeful sampling method to undergo the SSSI. Their teachers were then asked to take part in the TSSI.

\subsection{Instrument}

The ScAT was adapted from the paper and pencil argumentation instrument developed by Schen (2007). It was then further developed according to the fourth form Malaysian chemistry syllabus. The ScAT consists of three sections, where Section A is about neutralization, Section B is about the properties of acids and bases, and Section $\mathrm{C}$ is about the strength of acids and bases. Each section starts with a phenomenon, followed by some data, such as imaginary solutions $\mathrm{P}, \mathrm{Q}, \mathrm{R}, \mathrm{S}$ and $\mathrm{T}$, to assist students to solve six questions, related to scientific argumentation elements.

The SSSI was developed based on students' answers in the ScAT. The questions focused on the thinking process, especially on the arguments constructed by students. For example, questions such as "How do you know?" and "What are your reasons about...?" were presented to obtain additional information from the participants. The TSSI was developed as a support for the students' test and interview. The TSSI focused on the teacher's teaching methods, questioning techniques and class activities, and student's interactions and involvements during the teaching and learning of chemistry. The SSSI and TSSI were recorded, transcribed and analyzed.

\subsection{Data Collection and Data Analysis}

According to Laughlin, Hatch, Silver, and Boh (2006), the comparison between group and individual performances can be carried out by comparing $n$ groups of size $s$ with an equivalent number of ( $\left.n \times{ }^{2}\right)$ individuals. The average performance of the individual can then be compared to the average performance of the groups. Therefore, participants were randomly divided into two groups. Sixty (60) respondents engaged in individual argumentation first answered the ScAT. Another sixty (60) respondents, grouped into four respondents per group $(4 \times 15$ groups $=60)$ engaged in group argumentation. Since those in group argumentation were allowed to discuss among themselves, all the discussions were recorded.

Respondents in both argumentation activities answered the ScAT within the time allocated. The written answers were used to determine the score of each respondent based on the rubric, which was designed to assess students' scientific argumentation quality. The average score for both individual and group argumentations were then determined and compared. Each respondent's performances on the sub concepts of acids and bases, and their usage of scientific argumentation elements were also identified.

In order to establish reliability for the analysis, ten written answers (13\%) were examined collectively by two researchers to determine the respondent's scores. Another $20 \%$ of the written answers were examined 
independently by the two researchers based on the rubric. The outcomes of the scoring were discussed and all disagreements were resolved. The remaining $67 \%$ of written answers were analyzed by the first author. The mean score for all three analyses were calculated and students' mastery level of scientific argumentation were identified by referring to the Mastery Level Determination Table (MLDT), proposed by Heng et al. (2012). The MLDT is shown in Table 1.

The audio recordings of the discussions within group argumentation, students' interviews through the SSSI, and teachers' interviews through the TSSI were then transcribed and analyzed by the first author. The analyses was then used as a support to the ScAT results.

Table 1. Mastery level determination table

\begin{tabular}{ll}
\hline Mean Score (\%) & Mastery level \\
\hline $80.00-100.00$ & Excellent \\
$60.00-79.99$ & Good \\
$40.00-59.99$ & Moderate \\
$20.00-39.99$ & Weak \\
$0.00-19.99$ & Very weak \\
\hline
\end{tabular}

\section{Results and Discussion}

The data obtained from the ScAT were analyzed and presented in the form of tables and charts. Results from the SSSI and TSSI were also used to support the ScAT data to examine student's mastery of scientific argumentation.

\subsection{Mastery of Scientific Argumentation between Individuals and Groups}

To compare the mastery level of scientific argumentation between groups and individuals, the t-test was carried out to evaluate the differences in students' mean score. As shown in Table 2, the results indicated significant differences $(\mathrm{t}=-3.064, \mathrm{df}=118, \mathrm{p}<.05)$. The mean difference of -6.298 showed that students in group argumentation performed better than students engaged in individual argumentation. Similar results were also obtained when the data was analyzed with the chi-square test, where $\chi^{2}(3, \mathrm{~N}=120)=23.23, \mathrm{p}<.05$. In comparison, the mastery level of scientific argumentation for students involved in group argumentation was moderate $\left(\chi^{2}(2, \mathrm{~N}=60)=19.20, \mathrm{p}<.05\right)$, whereas the mastery level for students engaged in individual argumentation was weak $\left(\chi^{2}(3, \mathrm{~N}=60)=49.20, \mathrm{p}<.05\right)$.

Table 2. Independent samples test to compare the mastery of scientific argumentation between groups and individuals

\begin{tabular}{|c|c|c|c|c|c|c|c|c|c|c|}
\hline & & \multicolumn{2}{|c|}{$\begin{array}{c}\text { Levene's Test for } \\
\text { Equality of } \\
\text { Variances }\end{array}$} & \multicolumn{7}{|c|}{ t-test for Equality of Means } \\
\hline & & \multirow[b]{2}{*}{$\mathrm{F}$} & \multirow[b]{2}{*}{ Sig. } & \multirow[b]{2}{*}{$\mathrm{t}$} & \multirow[b]{2}{*}{ df } & \multirow{2}{*}{$\begin{array}{c}\text { Sig. } \\
\text { (2-tailed) }\end{array}$} & \multirow{2}{*}{$\begin{array}{c}\text { Mean } \\
\text { Difference }\end{array}$} & \multirow{2}{*}{$\begin{array}{l}\text { Std. Error } \\
\text { Difference }\end{array}$} & \multicolumn{2}{|c|}{$\begin{array}{c}95 \% \text { Confidence Interval } \\
\text { of the Difference }\end{array}$} \\
\hline & & & & & & & & & Lower & Upper \\
\hline \multirow[t]{6}{*}{ Score } & Equal & & & & & & & & & \\
\hline & variances & 3.381 & .068 & -3.064 & 118 & .003 & -6.29817 & 2.05566 & -10.36893 & -2.22741 \\
\hline & assumed & & & & & & & & & \\
\hline & Equal & & & & & & & & & \\
\hline & variances not & & & -3.064 & 114.660 & .003 & -6.29817 & 2.05566 & -10.37015 & -2.22618 \\
\hline & assumed & & & & & & & & & \\
\hline
\end{tabular}

Figure 2 shows the number of students (count) in each mastery level according to the argumentation activities. The figure indicated that a weak mastery level is the most common for individual argumentation and a moderate 
level is the most common for group argumentation. These findings are parallel with current literature, which reported that groups tend to perform better than individuals, especially for complex assignments or tasks related to conceptualization issue (Barron, 2000; Mason, 1998). This is because, in group argumentation, students get to contribute knowledge, combine different ideas, integrate different cognitive strength, and correct mistakes (Sampson \& Clark, 2009).

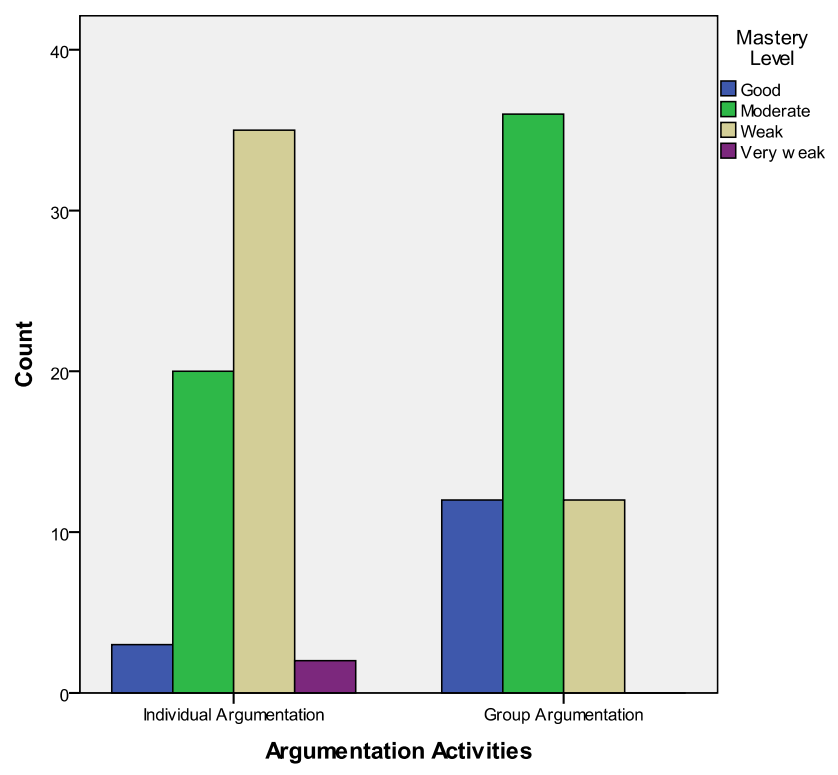

Figure 2. Comparison of student's performance in scientific argumentation through individual and group argumentations

An example of a discussion during group argumentation is shown in the transcript below. Note that all students' names were not their real names and the excerpts have been typed according to students' responses without any alterations to their grammar.

Annie: We want to take away the corrosive properties of mysterious alkali, use acid, right?

Murugan: I think should use water, right?

Yazid: $\quad$ No, we need acid.

Murugan: Why? Water can dilute it then remove the corrosive property.

Yazid: $\quad$ Water just dilute, we need to neutralize it.

Yen Li: $\quad$ pH must be high...

Annie: $\quad$ Ah...must be acid then!

Murugan: Why?

Yazid: Just like titration. Acid react with alkali, the product is salt and water. So, salt and water, no corrosive property. We need to choose $\mathrm{Q}$.

Yen Li: $\quad$ why Q? not P?

Annie: $\quad$ Must use strong acid, $\mathrm{pH}$ must be 1.

(Group argumentation 1)

From the transcript above, it can be observed that students who were involved in group argumentation shared ideas, detected and corrected other's mistakes, explained ideas, and listened to other's explanations. This process has resulted in a deeper understanding of the concepts being studied and further increased the group's performance in scientific argumentation. Furthermore, prompts and refutations in groups allow students to be aware of their weaknesses in their own arguments (Foong \& Daniel, 2013). Besides that, the total number of students in group argumentation who have a moderate mastery level or above is much higher than that of 
individual argumentation. This shows group activities foster student's scientific argumentation and improve their performance, which is aligned with the research findings of Erduran, Ardac, and Guzel (2006), McNeil and Martin (2011), and Schwarz, Neuman, Gil, and Ilya (2003).

However, the overall results, as depicted in Figure 2, showed that the mastery level of students in both individual and group argumentations were not satisfactory; since there is a majority with moderate and weak mastery levels. These findings are also in line with current literature, which reported that students tend to struggle with scientific argumentation (Jimenez-Aleixandre et al., 2000; McNeil, Lizotte, Krajcik, \& Marx, 2006; Osborne, Erduran, \& Simon, 2004). Similarly, these findings also agreed with the results published by Dawson and Venville (2009) and Erduran et al. (2006), which reported that school students have very poor reasoning capabilities. This is mainly caused by the lack of exposure to scientific argumentative activities (Heng \& Johari, 2013; Newton et al., 1999). Because the teaching and learning of science in school generally focuses on teacher oriented activities, they do not encourage the development of student's scientific argumentation. This scenario was proven by the TSSI conducted with chemistry teachers. The interviews showed that chemistry teachers seldom conduct group discussions, and classroom verbal interactions are mainly dominated by the teacher (Jegede \& Olajide, 1995). Teachers also rarely offer students the chance to reason out their answers (Foong \& Daniel, 2013). Hence, it can be concluded that classroom activities normally focuses on teacher explanation, which does not support the development of scientific argumentation (Heng \& Johari, 2013; Newton et al., 1999).

When analyzing the mastery level of the three sub concepts of acids and bases, it can be observed from Table 3 that the sub concept of neutralization is most mastered by students in both individual and group argumentations. For instance, the mean score for the sub concept of neutralization was $45.20 \%$ compared to $28.47 \%$ for the strength of acids and bases and $37.01 \%$ for properties of acids and bases in individual argumentation. These results aligned with the findings by Heng et al. (2012), which reported that the mastery level of the sub concept of neutralization among tertiary level science education students was better than that of the sub concepts of the strength and properties of acids and bases. This may be due to the fact that students have experience conducting experiments and writing reports related to the neutralization of acids and bases in school. Thus, students managed to provide claims with justifications based on their experiences.

Table 3. Mastery level of scientific argumentation between the three sub concepts of acids and bases

\begin{tabular}{ccccccc}
\hline Concept & \multicolumn{2}{c}{ Neutralization } & \multicolumn{2}{c}{ Strength of acids and bases } & \multicolumn{2}{c}{ Properties of acids and bases } \\
\hline $\begin{array}{c}\text { Argumentation } \\
\text { Activities }\end{array}$ & $\begin{array}{c}\text { Mean } \\
(\%)\end{array}$ & Mastery & Mean & Mastery & Mean & Mastery \\
& & $(\%)$ & Level & $(\%)$ & Level \\
\hline Individual & 45.20 & Moderate & 28.47 & Weak & 37.01 & Weak \\
Group & 50.27 & Moderate & 44.16 & Moderate & 44.72 & Moderate \\
\hline
\end{tabular}

To determine the effect of argumentative activities on the mastery level of scientific argumentation between the three sub concepts, Multivariate Analysis Of Variance Test was conducted. The results obtained from the Multivariate Tests are shown in Table 4. It can be observed that argumentative activities significantly affect the mastery level of the sub concepts being studied $(\mathrm{F}(3,116)=6.63, \mathrm{p}<.05)$. Further results from the Test of Between-Subjects Effects showed that argumentative activity was the significant factor of the mastery of scientific argumentation on the sub concepts of the strength of acids and bases $(F(1,118)=13.78, p<.05)$, and the properties of acids and bases $(\mathrm{F}(1,118)=5.17, \mathrm{p}<.05)$. The line graph in Figure 3 clearly shows that the mean score for students involved in group argumentation was higher than students involved in individual argumentation for the two sub concepts mentioned. Thus, the results suggested that collaboration through groups improves students' scientific argumentation skills, especially when they are engaged in a task with difficulties. In contrast, because students were familiar with the sub concept of neutralization, the difference was no significant $(\mathrm{F}(1,118)=.084, \mathrm{p}>.05)$.

However, the overall mastery level of scientific argumentation for the three sub concepts was still at moderate and weak levels, regardless of the argumentative activities. These are in line with the findings by Bradley and Mosimega (1998) and Sesen and Tarhan (2010), which stated that student's performance in those concepts was less satisfactory. This may be due to their lack of scientific knowledge in the concepts being studied (Foong \& Daniel, 2010). Hence, they performed poorly in the explanation and justification of their claims. Hence, this finding agrees with the results presented by Sampson and Clark (2011), which reported that students with high 
academic achievements have a higher mastery level in scientific reasoning and vice versa.

Table 4. Multivariate tests to compare the mastery level of scientific argumentation between the three sub concepts

\begin{tabular}{lllllll}
\hline Effect & & Value & F & Hypothesis df & Error df & Sig. \\
\hline Intercept & Pillai's Trace & .940 & $600.539^{\mathrm{a}}$ & 3.000 & 116.000 & .000 \\
& Wilks' Lambda & .060 & $600.539^{\mathrm{a}}$ & 3.000 & 116.000 & .000 \\
& Hotelling's Trace & 15.531 & $600.539^{\mathrm{a}}$ & 3.000 & 116.000 & .000 \\
& Roy's Largest & 15.531 & $600.539^{\mathrm{a}}$ & 3.000 & 116.000 & .000 \\
& Root & & & & & \\
\hline Argumentation & Pillai's Trace & .146 & $6.625^{\mathrm{a}}$ & 3.000 & 116.000 & .000 \\
activities & Wilks' Lambda & .854 & $6.625^{\mathrm{a}}$ & 3.000 & 116.000 & .000 \\
& Hotelling's Trace & .171 & $6.625^{\mathrm{a}}$ & 3.000 & 116.000 & .000 \\
& Roy's Largest & .171 & $6.625^{\mathrm{a}}$ & 3.000 & 116.000 & .000 \\
& Root & & & & & \\
\hline
\end{tabular}

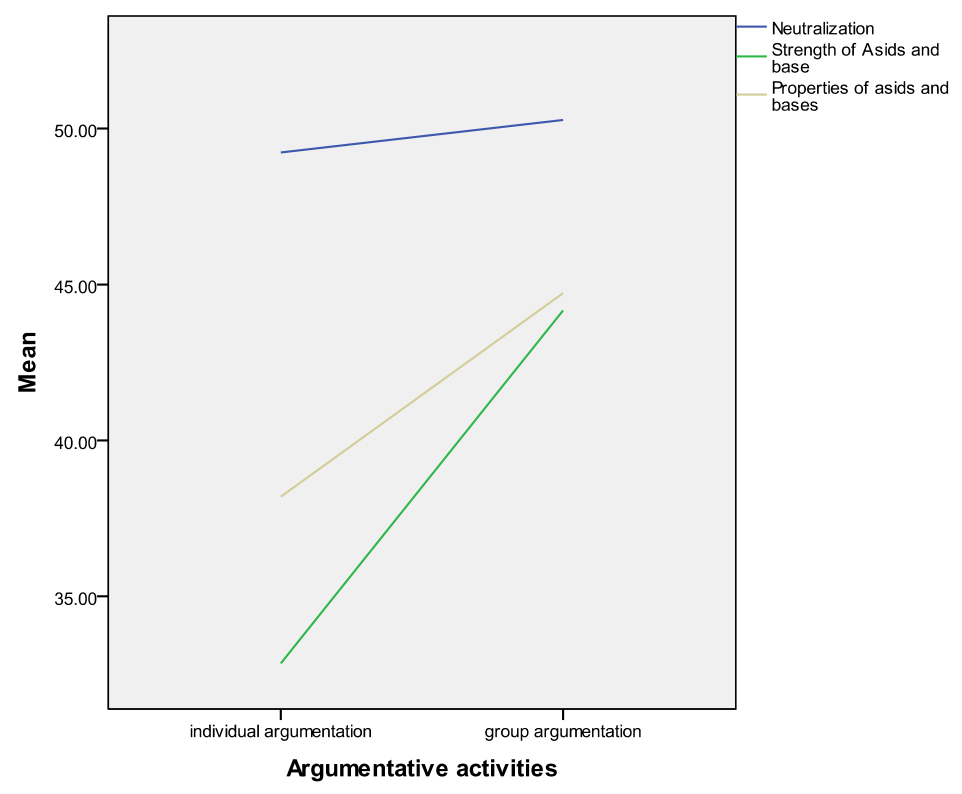

Figure 3. Comparison of mean score in student's scientific argumentation between three sub concepts of acids and bases by individual argumentation and group argumentation

Another reason for the poor mastery level of scientific argumentation on the concepts of acids and bases may be due to the existence of alternative frameworks, which act as a barrier in learning (Centingul \& Geban, 2005). It was discovered through this study that students' alternative frameworks were:

Strong acid would only react with strong alkali, and weak acid would only react with weak alkali.

Acid with low $\mathrm{pH}$ value is considered weak acid.

Only acid can conduct electricity.

Only alkali can conduct electricity.

The higher the molarity, the stronger the acid. 
In summary, students' poor performance in scientific argumentation related to the concepts of acids and bases is due to the lack of exposure to argumentative activities, poor scientific knowledge (Sampson \& Clark, 2011) and the existence of alternative frameworks (Centingul \& Geban, 2005; Hartley, Wike, Schram, D'Avanzo, \& Anderson, 2011). Thus, chemistry teachers need to be aware of these problems and take appropriate actions to trace students' alternative frameworks. One way to detect and eliminate students' alternative frameworks is by engaging students in argumentative activities, such as group discussions (Cross, Taasoobshirazi, Hendricks, \& Hickey, 2008).

\subsection{Mastery of Scientific Argumentation Elements}

It can be observed from Figure 4 that students involved in group argumentation outperformed students involved in individual argumentation for all argumentation elements. This once again supported the research findings by Erduran et al. (2006), McNeil and Martin (2011) and Schwarz et al. (2003). The mean score and mastery level for performance on scientific argumentation elements are presented in Table 5.

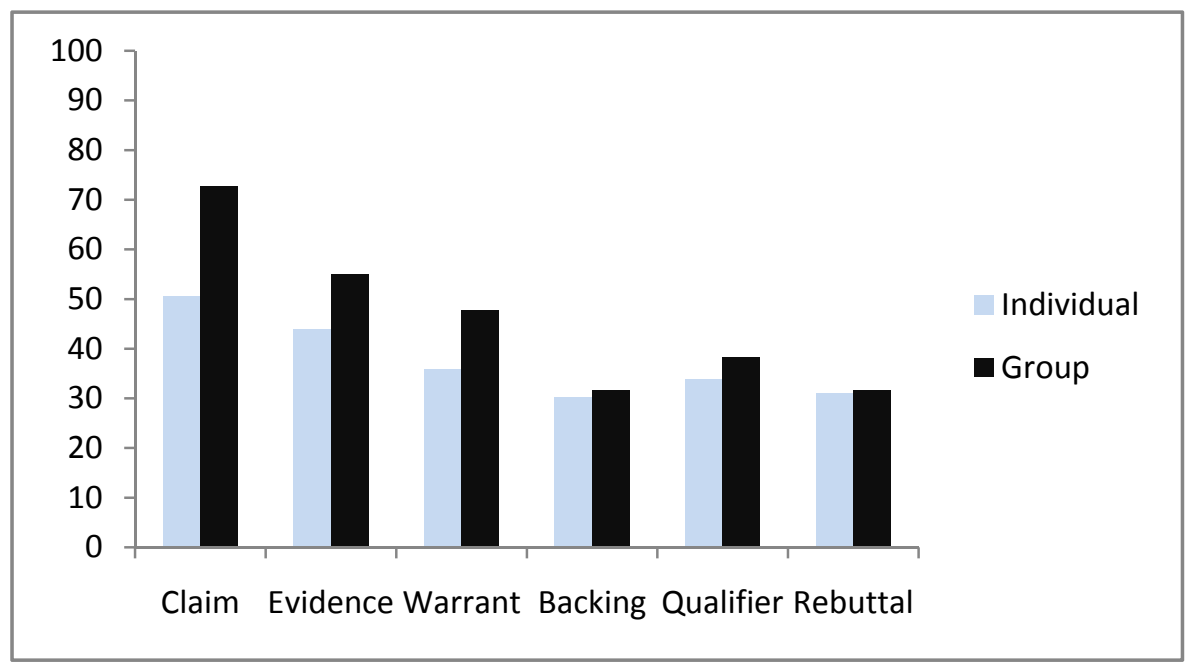

Figure 4. Comparison of the mastery (\%) of scientific argumentation elements between individual argumentation and group argumentation

Table 5. Comparison of the mean score and mastery level of scientific argumentation elements between individual argumentation and group argumentation

\begin{tabular}{lcccc}
\hline \multirow{2}{*}{ Element } & \multicolumn{2}{c}{ Individual Argumentation } & \multicolumn{2}{c}{ Group Argumentation } \\
\cline { 2 - 5 } & $\mathbf{\%}$ & Mastery Level & $\mathbf{\%}$ & Mastery Level \\
\hline Claim & 53.19 & Moderate & 72.78 & Good \\
Evidence & 47.50 & Moderate & 55.00 & Moderate \\
Warrant & 38.75 & Weak & 47.78 & Moderate \\
Backing & 31.94 & Weak & 32.78 & Weak \\
Qualifier & 36.39 & Weak & 37.77 & Weak \\
Rebuttal & 32.78 & Weak & 32.22 & Weak \\
\hline
\end{tabular}

The results in Table 5 showed that the mastery level of argumentation elements varies; from good $(72.78 \%$, element claim, group argumentation) to weak (31.94\%, element backing, individual argumentation). It can be observed that the mastery of the element claim was the highest among students in both individual argumentation (53.19\%, moderate) and group argumentation $(72.78 \%$, good). Meanwhile, the mastery of the element backing was the lowest among all argumentation elements and at weak level for both individual argumentation (31.94\%) and group argumentation (32.78\%). For this element, students were required to provide information about the 
assumptions that supported the warrants or information that strengthens the warrants. In this study, most students provided simple warrants without backings, even when they were asked to do so (Bell \& Linn, 2000). The SSSI showed that students have difficulties in providing backings to support their warrants. This may be caused by the lack of sufficient knowledge (Foong \& Daniel, 2010). As a result, students were not able to support their warrant with scientific knowledge (Zohar \& Nemet, 2002).

The results in Table 5 also showed that the mastery of element backing, qualifier and rebuttal was at weak level for both individual and group argumentations. These results indicated that students have problems constructing complex arguments that consisting of backing, qualifier and rebuttal. From the SSSI, it was observed that students could not provide qualifier or rebuttal for their answers, even though they were very confident that their answer was correct. These findings were corroborated with the studies by Dawson and Venville (2009), Osborne et al. (2004) and Heng et al. (2012), which reported that students' arguments tend to be simple, consisting of only one justification and having a simple structure. Examples of arguments provided by students are shown below:

Example 1: Zhi Yang, Individual argumentation (argument with alternative framework: claim and data)

Glacial ethanoic acid can light up the bulb (claim) because ethanoic acid is a strong acid (data).

Example 2: Jeremy, Individual argumentation (argument: claim, data, and warrant)

Calcium hydroxide solution can conduct electricity (claim) because it is in aqueous state (data). In aqueous state, water is present; alkali can show its property with the present of water (warrant).

In terms of the element evidence, the mastery of this element was at moderate levels for both argumentation activities. The findings showed that students did not use appropriate data and scientific knowledge to support their claim, which aligned with the findings by Zohar and Nemet (2002). Students encountered difficulties in differentiating between data and opinion; they relied heavily on personal belief in making scientific arguments (Sadler, Chambers, \& Zeidler, 2004).

The mastery of element warrant was also at a moderate level $(47.78 \%)$ for students involved in group argumentation. However, the mastery level was weak $(38.75 \%)$ for students who were engaged in individual argumentation. Students were unable to provide accurate scientific explanation on the answers given, even though the answers were correct (Mohd Ali et al., 2003). This situation is shown in the interview transcript below:

Researcher:

What happens to the solution when you add in the acidic solution?

Jamal:

$\mathrm{Mm} . .$. the two solutions react.

Researcher:

Can you explain how the reaction happens?

Jamal:

Mm... (shaking of head).

Researcher:

When you add acid to alkali, anything happen?

Jamal: .....(shaking of head and smiling).

(Jamal, student interview, individual argumentation)

The interview transcript above showed that students could not provide warrants to their claims, even though they were prompted by the researcher with questions. This again showed that students' limited content knowledge was the sole culprit. According to Dawson and Venville (2009), the teaching of explicit argumentation skills enhances students' performance in both conceptual understanding and argumentation. Thus, chemistry teachers need to emphasize on the explicit teaching of scientific argumentation structure and skills.

A Multivariate Pillai's Trace Test was also conducted to study the mastery level of scientific argumentation elemnts, as shown in Table 6 . The results in Table 6 showed that argumentative activities have a significant effect on students' mastery of scientific argumentation elements $(F(6,113)=4.204, p<.05)$. The results also showed that students involved in group argumentation performed better than students engaged in individual argumentation on the elements of claim $(\mathrm{F}(1,118)=21.35, \mathrm{p}<.05)$, evidence $(\mathrm{F}(1,118)=4.16, \mathrm{p}<.05)$, and warrant $(\mathrm{F}(1,118)=7.59, \mathrm{p}<.05)$. However, there were no significant differences for the elements of backing, qualifier and rebuttal. This indicated that collaboration in group argumentation only enhance students' mastery of simple arguments, which consists of the elements claim, evidence, and warrant. This also indicated that group argumentation do not affect the construction of complex arguments in scientific argumentation. This may be caused the lack of exercises and experiences in scientific argumentation, especially in the construction of complex arguments (Heng \& Johari, 2013). 
Table 6. Multivariate tests to compare the mastery level of scientific argumentation elements between group and individual argumentations

\begin{tabular}{llccccc}
\hline & Effect & Value & $\mathrm{F}$ & Hypothesis df & Error df & Sig. \\
\hline Intercept & Pillai's Trace & .933 & $262.159^{\mathrm{a}}$ & 6.000 & 113.000 & .000 \\
& Wilks' Lambda & .067 & $262.159^{\mathrm{a}}$ & 6.000 & 113.000 & .000 \\
& Hotelling's Trace & 13.920 & $262.159^{\mathrm{a}}$ & 6.000 & 113.000 & .000 \\
& Roy's Largest Root & 13.920 & $262.159^{\mathrm{a}}$ & 6.000 & 113.000 & .000 \\
\hline Activities & Pillai's Trace & .184 & $4.244^{\mathrm{a}}$ & 6.000 & 113.000 & .001 \\
& Wilks' Lambda & .816 & $4.244^{\mathrm{a}}$ & 6.000 & 113.000 & .001 \\
& Hotelling's Trace & .225 & $4.244^{\mathrm{a}}$ & 6.000 & 113.000 & .001 \\
& Roy's Largest Root & .225 & $4.244^{\mathrm{a}}$ & 6.000 & 113.000 & .001 \\
\hline
\end{tabular}

The lack of background knowledge about the structure of a quality scientific argument can also lead to the construction of poor quality arguments. In particular, interactions in group argumentation failed to help students to construct complex arguments when all group members are facing the same difficulties. This can be observed in the interview transcripts below:

Researcher: Can you give more information to support your point?

Moon See:

Researcher: Did you discuss with your group members on this question?

Moon See: $\quad$ Yes, but they don't know. We have no idea what to support this point.

(Moon See, student interview, group argumentation)

The transcript above showed that collaboration in group argumentation did not have any substantial impact on students when all of them have difficulties understanding the structure of scientic arguments (McNeil et al., 2006).

All in all, the findings indicated that students involved in group argumentation could construct better arguments when compared to students involved in individual argumentation. However, collaboration in group argumentation did not enhance students' performance when constructing complex arguments. This may be because students did not have enough content knowledge on the concepts of acids and bases (Bradley \& Mosimega, 1998) to enable them to express reasonable justifications to support the claims constructed (Zohar \& Nemet, 2002), and their lack of background knowledge about the structure of scientific arguments. Thus, collaboration in group argumentation did not show significant impact on the construction of complex arguments when all the group members were facing the same difficulties. Students would only benefit from group argumentation if they understood the elements required to construct a quality scientific argument and have enough scientific knowledge for them to share and combine different ideas, and to correct mistakes. Teachers need to help students in understanding the structure of scientific argumentation by explicitly teaching them the elements and equip them with sufficient content knowledge.

\section{Conclusion and Research Implications}

Scientific argumentation plays an important role in instilling scientific concepts in students, which is the core of reasoning capabilities and academic achievements. However, local studies have shown that students have problems mastering this skill (Heng et al., 2012; Mohd-Ali et al., 2003). One way to overcome this problem is to involve students in collaboration argumentative tasks. Thus, this study aims to compare students' mastery of scientific argumentation between individual and group argumentation and to compare students' mastery of scientific argumentation elements through individual and group argumentations.

In terms of students' mastery of scientific argumentation, the findings showed that there were significant differences between group and individual argumentations. This observation suggested that students involved in group argumentation performed better than students engaged in individual argumentation. This also aligned with current literature that suggests that collaboration is often beneficial when the task is complex or focuses on conceptual issues (Barron, 2000; Mason, 1998). However, regardless of individuals or groups, the mastery of scientific argumentation for all students was not satisfactory. This is due to the lack of experiences in 
constructing scientific arguments in science classes. In addition, the teaching and learning of science in Malaysia still focuses on teacher-oriented activities and did not expose students to argumentative tasks (Heng \& Johari, 2013). The results also indicated that collaboration between students in group argumentation improves their performances when engaging in difficult tasks or tasks that students had alternative frameworks.

In terms of the mastery of scientific argumentation elements, students involved in group argumentation outperformed students involved in individual argumentation. The results suggested that students involved in group argumentation performed better in using elements such as claim, evidence and warrant, when compared to students engaged in individual argumentation. However, there were no significant differences in performance for elements such as backing, qualifier and rebuttal. In general, students' mastery of scientific argumentation elements such as backing, qualifier and rebuttal was weak for both individual and group argumentations. This is due to the lack of exercises and experiences in scientific argumentation elements, especially in constructing complex arguments.

In conclusion, the results of this study showed that collaborative efforts in group argumentation enhance students' mastery level of scientific argumentation, but do no affect their mastery level on concepts that they are familiar with, such as neutralization. Besides, group argumentation can only improve students' mastery of simple argumentation elements. This showed that students lack exposure to scientific argumentative activities and lack experiences in constructing scientific arguments. Hence, students need to be taught explicitly on the elements of scientific argumentation and be involved in group argumentative activities, such as discussions, debates, question-answer sessions and presentations. The teaching and learning of science should also focus on group activities, which involve students expressing ideas, providing criticisms, discussing and revising ideas. This will enhance their scientific argumentation skills and thus improve their reasoning capabilities, as stated in the Malaysian Standard Curriculum for Primary School (KSSR).

\section{Acknowledgments}

The authors would like to thank the students and teachers who have participated in this research.

\section{References}

American Association for the Advancement of Science (AAAS). (1993). Benchmarks for Science Literacy. Retrieved June 20, 2012, from http://www.project2061.org/publications/bsl/

Amigues, R. (1988). Peer interaction in solving physics problems: Sociocognitive confrontation and metacognitive aspects. Journal of Experimental Child Psychology, 45(1), 141-158. http://dx.doi.org/10.1016/0022-0965(88)90054-9

Azmitia, M. (1988). Peer interaction and problem solving: When are two heads better than one? Child Development, 59(1), 87-96. http://dx.doi.org/10.2307/1130391

Barron, B. (2000). Problem solving in video-based microworlds: Collaboration and individual outcomes of high-achieving sixth grade students. Journal of Educational Psychology, 92(2), 391-398. http://dx.doi.org/10.1037/0022-0663.92.2.391

Bell, P., \& Linn, M. C. (2000). Scientific arguments as learning artifacts: Designing for learning from the web with KIE. International Journal of Science Education, 22(8), 797-817. http://dx.doi.org/10.1080/095006900412284

Braaten, M., \& Windschitl, M. (2011). Working toward a stronger conceptualization of scientific explanation for science education. Science Education, 95(4), 639-669. http://dx.doi.org/10.1002/sce.20449

Bradley, J. D., \& Mosimega, M. D. (1998). Misconceptions in acids and bases: A comparative study of student teachers with different chemistry backgrounds. South African Journal of Chemistry, 51(3), 137-145.

Cavagnetto, A. R. (2010). Argument to foster scientific literacy: A review of argument interventions in K-12 science contexts. Review of Educational Research, 80(3), 336-371. http://dx.doi.org/10.3102/0034654310376953

Centingul, P. I., \& Geban, O. (2005). Understanding of acid-base concept by using conceptual change approach. H. U. Journal of Education, 29, 69-74.

Cohen, E. G. (1994). Restructuring the classroom: Conditions for productive small groups. Review of Educational Research, 64, 1-35. http://dx.doi.org/10.3102/00346543064001001

Coleman, E. B. (1998). Using explanatory knowledge during collaborative problem solving in science. The Journal of The Learning Sciences, 7(3,4), 387-427. http://dx.doi.org/10.1080/10508406.1998.9672059 
Cross, D., Taasoobshirazi, D., Hendricks, S., \& Hickey, D. T. (2008). Argumentation: A strategy for improving achievement and revealing scientific identities. International Journal of Science Education, 30(6), 837-861. http://dx.doi.org/10.1080/09500690701411567

Dawson, V., \& Venville, G. J. (2009). High-school student's informal reasoning and argumentation about biotechnology: An indicator of scientific literacy? International Journal of Science Education, 31(11), 1421-1445. http://dx.doi.org/10.1080/09500690801992870

Driver, R., Newton, P., \& Osborne, J. (2000). Establishing the norms of scientific argumentation in classrooms. $\begin{array}{lll}\text { Science } & \text { Education, } & \text { 287-312. }\end{array}$ http://dx.doi.org/10.1002/(SICI)1098-237X(200005)84:3<287::AID-SCE1>3.0.CO;2-A

Duschl, R. A., \& Osborne, J. (2002). Supporting and promoting argumentation discourse in science education. Studies in Science Education, 38, 39-72. http://dx.doi.org/10.1080/03057260208560187

Erduran, S., Ardac, D., \& Guzel, B. Y. (2006). Learning to teach argumentation: Case studies of pre-service secondary science teachers. Eurasia Journal of Mathematics, Science and Technology Education, 2(2).

Erduran, S., Simon, S., \& Osborne, J. (2004). TAPing into argumentation: Developments in the application of Toulmin's Argumentation Pattern for studying science discourse. Science Education, 88(6), 915-933. http://dx.doi.org/10.1002/sce.20012

Eskin, H., \& Berkiroglu, F. O. (2008). Investigation of a pattern between students' engagement in argumentation and their science content knowledge: A case study. Eurasia Journal of Mathematics, Science \& Technology Education, 5(1), 63-70.

Foong, C. C., \& Daniel, E. G. S. (2010). Incompetent grounds in science students' arguments: What is amiss in the argumentation process? Procedia Social and Behavioral Science, 9(2010), 1198-1207. http://dx.doi.org/10.1016/j.sbspro.2010.12.307

Foong, C. C., \& Daniel, E. G. S. (2013). Students' argumentation skills across two socio-scientific issues in a Confusian classroom: Is transfer possible? International Journal of Science Education, 35(14), 2331-2355. http://dx.doi.org/10.1080/09500693.2012.697209

Hartley, L. M., Wike, B. J., Schram, J. W., D’Avanzo, C., \& Anderson, C. W. (2011). College Students' Understanding of Carbon Cycle: Contrasting Principle-based and Informal Reasoning. BioScience, 61(1), 63-75. http://dx.doi.org/10.1525/bio.2011.61.1.12

Heng, L. L., \& Johari, B. S. (2013). Penghujahan Saintifik: Memahami Perlaksanaannya dalam Proses Pengajaran dan Pembelajaran Kimia (Scientific argumentation: understanding the process of implementation of teaching and learning of Chemistry). Jurnal Teknologi (Social Sciences), 65(1), 1-8.

Heng, L. L., Johari, B. S., \& Yazid, A. M. (2012, September). Penguasaan Penaakulan Saintifik Pelajar Pendidikan Opsyen Sains Terhadap Konsep Asid and Bes (The mastery of scientific reasoning among science option education students on acids and bases concept). Paper presented at International Seminar in Science and Mathematics Education, Universiti Teknologi Malaysia, Skudai.

Heng, L. L., Johari, S., \& Seng, C. H. (2013, July). Students'performance in scientific argumentation: Individual versus group. Paper presented at International Conference on Education, Psychology and Society (ICEPAS), Bangkok, Thailand.

Hong, K. S., \& George T. G. S. (2011). The effectiveness of collaborative learning in the teaching of form four mathematical reasoning. Journal Teknologi (Sains \& Sosial), 55, 55-73.

Jegede, O. J., \& Olajide, J. O. (1995). Wait-time, classroom discourse, and the influence of sociocultural factors in science teaching. Science Education, 79(3), 233-249. http://dx.doi.org/10.1002/sce.3730790302

Jiménez-Aleixandre, M. P., Rodriguez, A. B., \& Duschl, R. A. (2000). "Doing the lesson" or "doing science": argument in high school genetics. Science Education, 84, 757-792. http://dx.doi.org/10.1002/1098-237X(200011)84:6<757::AID-SCE5>3.0.CO;2-F

King, A. (1990). Enhancing peer interaction and learning in the classroom through reciprocal questioning. American Educational Research Journal, 27(4), 664-687. http://dx.doi.org/10.3102/00028312027004664

Kurikulum Standard Sekolah Rendah (KSSR). (2011). Retrieved February 5, 2012, from http://web.moe.gov.my/bpk/v2/index.php?option=com_content\&view=article\&id=168\%3Akurikulum-stand ard-sekolah-rendah-suatu-pengenalan\&catid $=101 \% 3$ Aslideshow\&lang=en 
Laughlin, P., Hatch, E., Silver, J., \& Boh, L. (2006). Group perform better than individuals on letters-to-numbers problems: Effects of group size. Journal of Personality and social Psychology, 90(4), 644-651. http://dx.doi.org/10.1037/0022-3514.90.4.644

Marttunen, M. (1994). Assessing argumentation skills among Finnish university students. Learning and Instruction, 4, 175-191. http://dx.doi.org/10.1016/0959-4752(94)90010-8

Mason, L. (1996). An Analysis of children's construction of new knowledge through their use of reasoning and arguing in classroom discussions. Qualitative Studies in Education, 9(4), 411-433. http://dx.doi.org/10.1080/0951839960090404

Mason, L. (1998). Sharing cognition to construct scientific knowledge in school context: The role of oral and written discourse. Instructional Science, 26, 359-389. http://dx.doi.org/10.1023/A:1003103213786

McNeill, K. L., \& Martin, D. M. (2011). Claims, evidence, and reasoning: Demystifying data during a unit on simple machines. Science and Children, April/May 2011.

McNeill, K. L., \& Pimentel, D. S. (2010). Scientific discourse in three urban classrooms: The role of the teacher in engaging high school students in argumentation. Science Education, 94(2), 203-229.

McNeill, K. L., Lizotte, D. J., Krajcik, J., \& Marx, R. W. (2006). Supporting students' construction of scientific explanations by fading scaffolds in instructional materials. The Journal of the Learning Sciences, 15(2), 153-191. http://dx.doi.org/10.1207/s15327809j1s1502_1

Mohd-Ali, B. I., \& Shaharom, B. N. (2003). Perbandingan pencapaian para pelajar dalam pentaksiran kerja amali dengan peperiksaan bertulis (Comparison of students' achievement in practical work assessment and written examination). Buletin PerSCATuan Pendidikan Sains dan Matematik Johor, 12(1), 14-27.

Mohd-Ali, S., Salmiza, S., Zurida, H. I., \& Ahmad-Nurulazam, M. Z. (2003). Kefahaman dan kerangka alternatif konsep haba di kalangan pelajar-pelajar tingkatan empat. The Classroom Teacher, 8(1).

National Science Education Standards. (1996). Retrieved June 19, 2012, from http://www.nap.edu/openbook.php?record_id=4962\&page=209

Newton, P., Driver, R., \& Osborne, J. (1999). The place of argumentation in the pedagogy of school science. International Journal of Science Education, 21(5), 553-576. http://dx.doi.org/10.1080/095006999290570

Nussbaum, E. M. (2011). Argumentation, dialogue theory, and probability modeling: Alternative frameworks for argumentation research in education. Educational Psychologist, 46(2), 84-106. http://dx.doi.org/10.1080/00461520.2011.558816

Nussbaum, E. M., \& Sinatra, G. M. (2003). Argument and conceptual engagement. Contemporary Educational Psychology, 28(3), 384-395. http://dx.doi.org/10.1016/S0361-476X(02)00038-3

Osborne, J., Erduran, S., \& Simon, S. (2004). Enhancing the quality of argumentation in school science. Journal of Research in Science Teaching, 41(10), 994-1020. http://dx.doi.org/10.1002/tea.20035

Phelps, E., \& Damon, W. (1989). Problem solving with equals: Peer collaboration as a context for learning mathematics and spatial concepts. Journal of Educational Psychology, 81(4), 639-646. http://dx.doi.org/10.1037/0022-0663.81.4.639

Sadler, T. D. (2004). Informal reasoning regarding socioscientific issues: A critical review of research. Journal of Research in Science Teaching, 41(5), 513-536. http://dx.doi.org/10.1002/tea.20009

Sadler, T. D., Chambers, F. W., \& Zeidler, D. L. (2004). Student conceptualizations of the nature of science in response to a socioscientific issue. International Journal of Science Education, 26(4), 387-409. http://dx.doi.org/10.1080/0950069032000119456

Sampson, V., \& Clark, D. B. (2009). The impact of collaboration on the outcomes of scientific argumentation. Science Education, 93(3), 448-484. http://dx.doi.org/10.1002/sce.20306

Sampson, V., \& Clark, D. B. (2011). A comparison of the collaborative Scientific Argumentation Practices of two high and two low performing groups. Research in Science Education, 41, 63-97. http://dx.doi.org/10.1007/s11165-009-9146-9

Sandoval, W. A., \& Reiser, B. J. (2004). Explanation-driven inquiry: Integrating conceptual and epistemic scaffolds for scientific inquiry. Science Education, 88(3), 345-372. http://dx.doi.org/10.1002/sce.10130

Schen, M. S. (2007) Scientific Reasoning Skills Development in the Introductory Biology Courses for Undergraduates (Unpublished doctoral dissertation). The Ohio State University, United States. 
Schwarz, B. B., Neuman, Y., Gil, J., \& Ilya, M. (2003). Construction of collective and individual knowledge in argumentative activity. The Journal of the Learning Science, 12(2), 219-256. http://dx.doi.org/10.1207/S15327809JLS1202_3

Sesen, B. A., \& Tarhan, L. (2010). Promoting active learning in high school chemistry: Learning achievement and attitude. Procedia Social and Behavioral Science, 2(2010), 2625-2630. http://dx.doi.org/10.1016/j.sbspro.2010.03.384

Simon, S., Erduran, S., \& Osborne, J. (2006). Learning to Teach Argumentation: Research and development in the science classroom. International Journal of Science Education, 28(2-3), 235-260. http://dx.doi.org/10.1080/09500690500336957

Tay, C. S., \& Arshad, M. Y. (2008, October). Interaksi verbal pengajaran dan pembelajaran sains sekolah rendah (Verbal interaction in teaching and learning primary science). Paper presented at the National Seminar on Science and Mathematics Education, Universiti Teknologi Malaysia, Skudai.

Toulmin, S., Rieke, R., \& Janik, A. (1979). An Introduction to reasoning. New York: Macmillan Publishing Co., Inc.

Webb, N. M. (1985). Verbal interaction and learning in peer-directed groups. Theory into Practice, 24(1), $32-39$. http://dx.doi.org/10.1080/00405848509543143

Zembal-Saul, C. (2009). Learning To Teach Elementary School Science as Argument. Science Education, 93(4), 687-719. http://dx.doi.org/10.1002/sce.20325

Zohar, A., \& Nemet, F. (2002). Fostering students' knowledge and argumentation skills through dilemmas in human genetic. Journal of Research in Science Teaching, 39(1), 35-62. http://dx.doi.org/10.1002/tea.10008

\section{Appendix}

Example of Scientific Argumentation Test (ScAT)

Mystery Alkali Solution (Neutralisation)

During the investigation in a dilapidated house, you and your friend are trapped in the cellar. There is a solution bottle labeled "strong mystery alkali" in front of the door and five other solutions P, Q, R, S and T in a box. You and your friend try to escape but are stopped by the "strong mystery alkali" solution which is placed in front of the door (Figure A.1). To save yourself, you need to remove the strong corrosive property of the mystery alkali solution. You received information that one of the solutions $\mathrm{P}, \mathrm{Q}, \mathrm{R}, \mathrm{S}$ and $\mathrm{T}$ has the potential to remove the strong corrosive property of the mystery alkali solution. You and your friend have carried out several tests on the solutions P, Q, R, S and T. Table 1 shows the data you collected to help you solve your problem.

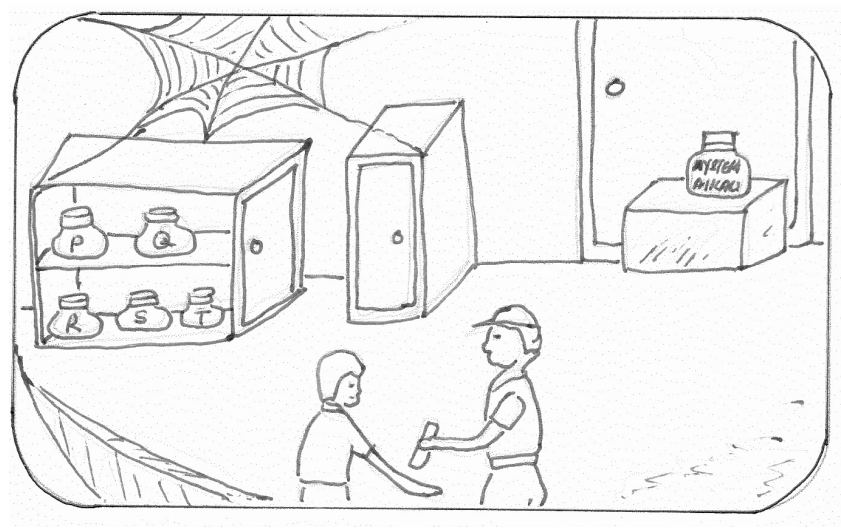

Figure A1. Situation in the cellar 
Table A1. Collected data

\begin{tabular}{|c|c|c|c|c|c|}
\hline Solution & $\mathrm{pH}$ & Reaction with metal & $\begin{array}{l}\text { Reaction with } \\
\text { carbonate }\end{array}$ & $\begin{array}{l}\text { Colour of blue } \\
\text { litmus paper }\end{array}$ & $\begin{array}{c}\text { Colour of } \\
\text { phenolphthalein }\end{array}$ \\
\hline $\mathrm{P}$ & 5 & $\begin{array}{l}\text { Hydrogen gas is } \\
\text { produced }\end{array}$ & $\begin{array}{c}\text { Carbon dioxide gas is } \\
\text { produced }\end{array}$ & Red & Colourless \\
\hline Q & 1 & $\begin{array}{l}\text { Hydrogen gas is } \\
\text { produced }\end{array}$ & $\begin{array}{l}\text { Carbon dioxide gas is } \\
\text { produced }\end{array}$ & Red & Colourless \\
\hline $\mathrm{R}$ & 13 & No changes & No changes & No changes & Pink \\
\hline $\mathrm{S}$ & 8 & No changes & No changes & No changes & Pink \\
\hline $\mathrm{T}$ & 7 & No changes & No changes & No changes & Colourless \\
\hline
\end{tabular}

Questions:

1) What is the conclusion that you can draw from the data collected to solve your problem?

2) What data are you using to support your conclusion? Explain your answer.

3) Give the reasons how you link this data to support your conclusion?

4) How do you explain that the relationship between data and your conclusion (answer in no. 3) is reliable/accurate? Explain your answer.

5) Your friend is in doubt over your conclusion. How sure are you that your conclusion is correct in all conditions? Give reason or conditions that support your answer.

6) State if there are other conditions which you think may affect your conclusion or may cause your conclusion to be inaccurate? Explain your answer.

\section{Copyrights}

Copyright for this article is retained by the author(s), with first publication rights granted to the journal.

This is an open-access article distributed under the terms and conditions of the Creative Commons Attribution license (http://creativecommons.org/licenses/by/3.0/). 